\title{
Environmental degradation and global warming-consequences of Himalayan mega dams: a review
}

\author{
M. Tajuddin Sikder ${ }^{1,2, *}$, K. Maudood Elahi ${ }^{1}$ \\ ${ }^{1}$ Department of Environmental Science, Stamford University Bangladesh, Dhaka, Bangladesh \\ ${ }^{2}$ Graduate School of Environmental Science, Hokkaido University, Sapporo, Japan
}

Email address:

sikder@ees.hokudai.ac.jp (M. T. Sikder), sikder.stamford@yahoo.com (M. T. Sikder)

To cite this article:

M. Tajuddin Sikder, K. Maudood Elahi. Environmental Degradation and Global Warming- Consequences of Himalayan Mega Dams: A Review, American Journal of Environmental Protection. Vol. 2, No. 1, 2013, pp. 1-9. doi: 10.11648/j.ajep.20130201.11

\begin{abstract}
Mega dams have been considered as the greener energy source than most alternatives. But, responses of environment to dams are complex and varied, as it may result a wide range of environmental degradation. as they depend on local climate, dam structure and operation, and key attributes of the biota. We review our research and that of others to illustrate the fact of environmental impacts due to the existing and proposed mega dams of the Himalayas and also to investigate the sustainability of the dams. Being the youngest and fastest changing mountain, the Himalayas and it mighty glaciers, sources of important rivers, are highly susceptible to global warming. Recently, there are plans to transform the Himalayan Rivers into the powerhouse of South Asia by building hundred of mega dams to generate 150,000-megawatt electricity in the next 20 years. These dams pose severe environmental risks in the Himalayan region and mostly in the downstream and the climate change associated with the global warming threatens the safety and viability of these hydropower projects. Dams and their associated reservoirs impact freshwater biodiversity and hydrogeology; changing turbidity, sediment levels, nutrient levels; causing flash flood and prolonged submergence; severe drought in dry season; affecting local ecology and habitat; contribute greenhouse gases and the resulting global warming; dry up the rivers for even longer lengths; impact traditional livelihoods, agriculture, irrigation and fisheries; threat political, regional and geo-strategic stability; increase the rate of disaster associated with the dam failure, land sliding, earthquake in the downstream. The study investigates the fact that the next hydrological projects in the Himalayas need proper EIA and information sharing to decrease the environmental impacts, to ensure water distribution of rivers, the riparian countries, to make the projects sustainable and to ensure benefits for all with proper negotiations and commitment.
\end{abstract}

Keywords: Mega Dams, Climate Change, Global Warming, Environmental Degradation, Ecosystem, Biodiversity Loss

\section{Introduction}

Dams, once considered the blessing of mankind are nowa-days becoming the concern of environment. Dams, including the large dams, are usually constructed because of the potential benefits that they bring; firstly, water for increased food production, secondly, generation of electric power without releasing atmospheric pollutants or greenhouse gases and for controlling floods and providing drinking water [1]. The world's river flow is regulated about $60 \%$. There are more than 40,000 large dams and more than 100 dams with heights more than $150 \mathrm{~m}$. Reservoirs cover a total area in excess of $500,000 \mathrm{~km} 2$ [2].The Himalaya region of the world is one of the largest dam oriented area is now undergoing rapid change from global warming. For example, glaciers in the Tibetan Plateau are melting at a "worrisome speed and over the past 40 years, Tibetan glaciers have receded 196 square KM, or 1/4 the size of New York City [3]. Despite such loss of glaciers that feed important rivers in Asia; India, Pakistan, Nepal and Bhutan plan to build hundreds of mega-dams to power South Asia. The environmental consequences of large dams are abundant and diverse, and include direct impacts to the biological, chemical and physical properties of rivers and riparian (or "stream-side") environments. These dams will bring rigorous damage to the low riparian country like Bangladesh having 57 trans-boundary rivers shares with her neighboring countries; 54 with India and 3 with Myanmar 
[4]. Each year about 2.4 billion tons of sediment from the Himalayas is carried by the rivers of Bangladesh to the Bay of Bengal and contributes significant role to the environmental management and socioeconomic sector of this country [5].

While a lot of voices are being generated over the issue of the Tipaimukh Dam in both Bangladesh and India, we are still unaware as to what is happening all across the Himalayas, extending from the Pamir in Pakistan to the Arakan Yoma in Myanmar, in matter of management of water resources. This matter does not concern only a particular country but the whole of South Asian subcontinent, and the environment of the riparian countries is likely to be most terribly affected. This study brings forth some of the relatable issues that we should give importance for the sake of environmental reflection as well as sustainable water management of the entire region. This study intends to search the fact of environmental impacts due to the existing and proposed mega dams of the Himalayas by analysis some case study. Figure 1, shows some proposed, under construction and existing major dams projects in the Himalayan region. The existing dams have already geared up the deterioration of the downstream envrionment like Bangaldesh and now the under construction and proposed dams will raise the rate of threat in this area.

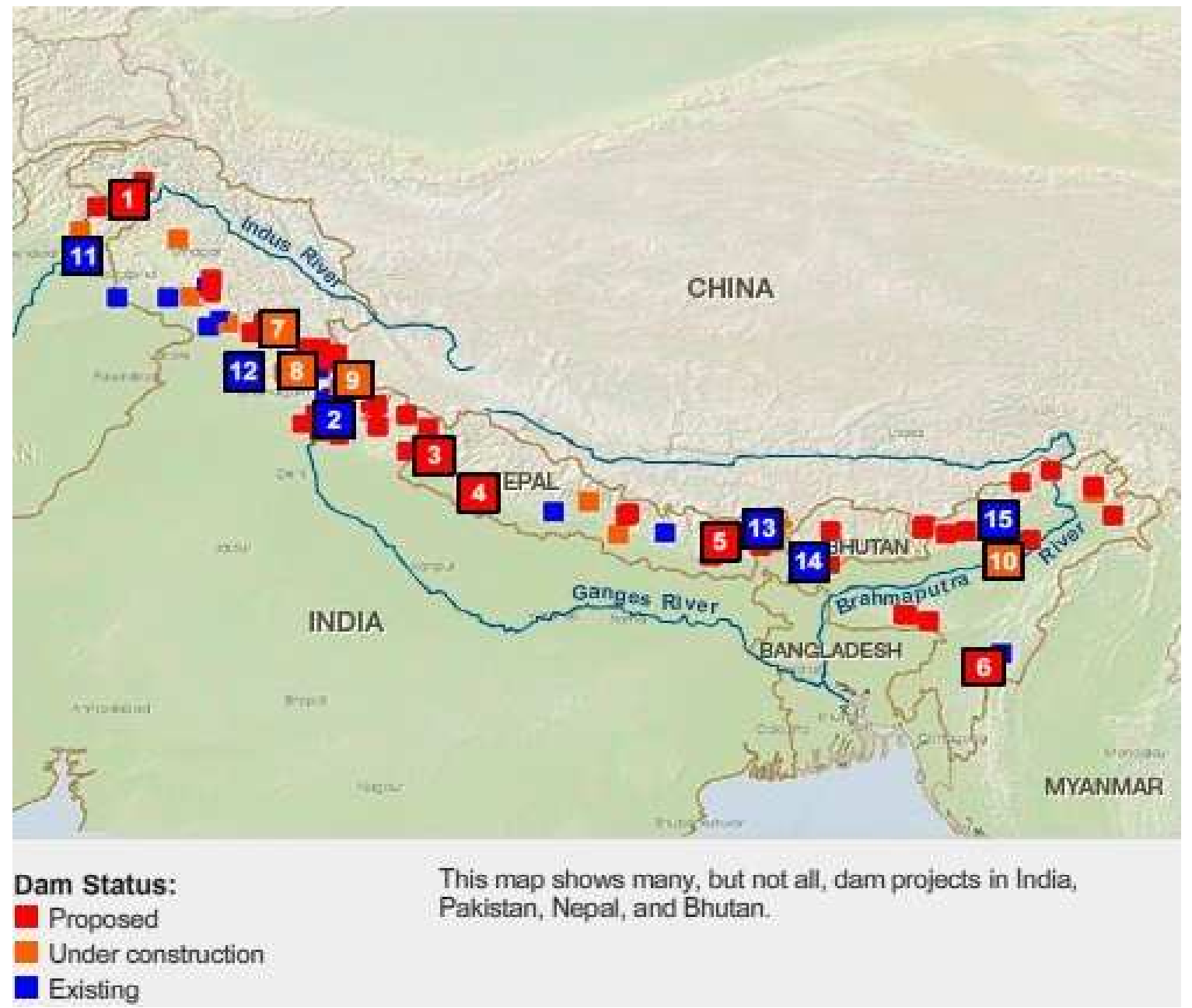

Figure 1. Mega dam projects in the Himalaya region [6].

\section{Large Dams}

Large dams with more than $15 \mathrm{~m}$ height from foundation to crest. Dams of 10-15 m of height can also be defined as large dams if they meet the following criteria: crest length $500 \mathrm{~m}$ or more; reservoir capacity of at least one million cubic meters; highest flood discharge of at least 2,000 m3S1; 'especially difficult' foundation problems, or 'abnormal design.' Major dams meet one or more of the following standards: at least $150 \mathrm{~m}$ high; having a volume of at least
15 million $\mathrm{m} 3$; reservoir capacity of at least $25 \mathrm{~km} 3$; or generation capacity of at least one G-watt. There are 306 major dams in the world and 57 new dams are planned in the near future [7]. Construction of large dams includes the making of access roads, preparation of the reservoir quarry, construction of buildings and dams within and between river diversions, digging of canals and erection of power lines. Forested reservoir basins provide fastidious challenges. Leaving some trees may provide fish habitat although leaving trees in any quantity may pose problems for 
future fishing, water quality and turbine protection [8]. While most reservoirs tend to trap sediments, e.g. a new delta is being formed within Lake Nasser [9], in some cases e.g. South Indian Lake Manitoba, [10], the exposure of clay soils to shifting reservoir water levels amplify erosion and downstream sediment discharge.

The quantity of water discharged during seasonal cycles relative to the river's natural flow pattern and abiotic distinctiveness of the discharge such as temperature, oxygen, turbidity and water quality- significantly affect downstream biodiversity [11].

\section{Environmental Consequences}

\subsection{Impacts of Dams on Biodiversity}

Biodiversity is most likely to be considered upon four grades- genetic; species; ecosystem and ecological function. The natural balance has so far been maintained by the worthy biodiversity and for its diversified roles. Perturbations to a species status can be measured by reduced population sizes, extirpations (loss of populations from a part of the species range), or extinction (loss of all individuals of a species). Finer levels of species loss categorized by IUCNextinct, extinct in the wild, endangered, data deficient and under evaluated. The mega dams are triggering strength to pendulant this natural equilibrium and directing the species into the above mentioned extinction classes. This loss of biodiversity is generally confined around dam adjacent area and gradually the impacts run the long distance cause future epidemic [12].

The dam wall itself blocks fish migrations, which in some cases and with some species completely split spawning habitats from rearing habitats. The dam also traps sediments, which are very important for downstream habitats and other physical process (include the maintenance of productive deltas, barrier islands, fertile floodplains and coastal wetlands).

The mega dams transformed the free flowing upstream river ecosystem to an artificial slack-water reservoir habitat.
The aquatic plants and animals in the reservoir are often not suitable for the changes in temperature, chemical composition, dissolved oxygen levels and the physical properties of a reservoir induced by the mega dams. Such reservoir with extreme climatic changes may invite non-native and invasive species (e.g. snails, algae, and predatory fish) that further undermine the river's natural communities of plants and animals. The change of a river's flow and sediment transport downstream of a dam often results the greatest sustained environmental impacts. Yet even slight changes in the quantity and timing of water flows affect aquatic and riparian life, which can unravel the ecological web of a river system [13].

A dam traps sediments that would naturally replenish downstream ecosystems. When a river's sediment flow is somehow deprived, it seeks to recapture it by eroding the downstream river bed and banks (which can undermine bridges and other riverbank structures, as well as riverside woodlands). The downstream of dams are generally eroded by several meters within the decade of first closing a dam; the damage can extend for tens or even hundreds of kilometers below a dam [14]. In addition, it also caused extreme salinity problem in the downstream, eg. Bangladesh (Table 1). Riverbed deepening can also lower groundwater tables along a river that hampers the plant roots to reach into the ground water (and to human communities drawing water from wells). The changes also reduce habitats- for fish that spawn in river bottoms, and for invertebrates. Mega dams have worst effect on the total biosphere. Most reservoirs are contributing about $4 \%$ of human-caused greenhouse gases in tropics. Recent studies on the Congo River have demonstrated that the sediment and nutrient flow from the Congo drives biological processes far into the Atlantic Ocean, including serving as a carbon sink for atmospheric greenhouse gases. Large dams have led to the extinction of many fish and other aquatic species, the disappearance of birds in floodplains, huge losses of forest, wetland and farmland, erosion of coastal deltas, and many other impacts (Table 2).

Table 1. Pre- and post-Farakka average monthly maximum salinity at four stations in southwest Bangladesh. Salinity expressed in micro-mhos/cm (mmhos $\left(\mathrm{cm}\right.$ ) and measured at $25^{\circ} \mathrm{C}$.

\begin{tabular}{|c|c|c|c|c|c|c|c|c|c|c|}
\hline \multirow{2}{*}{ Station } & \multicolumn{2}{|l|}{ January } & \multicolumn{2}{|l|}{ February } & \multicolumn{2}{|l|}{ March } & \multicolumn{2}{|l|}{ April } & \multicolumn{2}{|l|}{ May } \\
\hline & $\begin{array}{l}\text { Pre- } \\
\text { Farakka }\end{array}$ & $\begin{array}{l}\text { Post- } \\
\text { Farakka }\end{array}$ & $\begin{array}{l}\text { Pre- } \\
\text { Farakka }\end{array}$ & $\begin{array}{l}\text { Post- } \\
\text { Farakka }\end{array}$ & $\begin{array}{l}\text { Pre- } \\
\text { Farakka }\end{array}$ & $\begin{array}{l}\text { Post- } \\
\text { Farakka }\end{array}$ & $\begin{array}{l}\text { Pre- } \\
\text { Farakka }\end{array}$ & $\begin{array}{l}\text { Post- } \\
\text { Farakka }\end{array}$ & $\begin{array}{l}\text { Pre- } \\
\text { Farakka }\end{array}$ & $\begin{array}{l}\text { Post- } \\
\text { Farakka }\end{array}$ \\
\hline Khulna & 293 & 1,254 & 371 & 3,396 & 467 & 8,305 & 1,626 & 12,149 & 1,508 & 11,208 \\
\hline $\begin{array}{l}\text { Goalpara } \\
\text { Power Station }\end{array}$ & 340 & 515 & 397 & 1,303 & 750 & 4,422 & 1,320 & 7,422 & 786 & 5,456 \\
\hline Chalna & 2,600 & 6,280 & 2,625 & 11,510 & 8,950 & 17,310 & 8,675 & 21,927 & 12,000 & 19,009 \\
\hline Mongla & 2,300 & 5,200 & 3,900 & 7,880 & 7,500 & 11,075 & 11,800 & 17,150 & 13,500 & 17,100 \\
\hline
\end{tabular}


Table 2. Characteristics of 'environmentally friendly' and 'environmentally threatening' dams from a species diversity viewpoin.

\section{Environmentally friendly}

tNo genetically distinct stocks or species extirpated or driven to extinction

Only small areas of ecosystems/habitats lost or converted

'Footprint' of dam avoids areas rich in species, endemic species, species at risk, or diverse habitats

Highly productive inland rivers, lakes and estuaries are retained in their natural state

Overall 'footprint' of dam is small in area

No exotic species or ecosystems introduced

Dam does not block routes of migratory freshwater species

Seasonal flow patterns of discharge maintained

Discharge volume is little diminished. Water never ceases flowing.

Water quality natural. No methyl mercury generated.

Unique habitats conserved

Excellent EIA conducted and impacts avoided or mitigated

Environmental staff are an important part of the dam planning and construction team from project start

Landscape and airspace planning and management are included in the process to enhance dam performance and lower water demand.

Water volume stored is relatively small, but efficiency is high

Protected land and freshwater areas created to enhance dam performance and conserve biodiversity

Dam and irrigation canals leak-proof and evaporation minimized

Dam reservoir sedimentation rate low

Pumped storage units, hydrogen conversion or other techniques used to store power instead of storing high water volumes, fostering more normal seasonal water flow patterns and volumes

No genetically distinct stocks or species extirpated or driven to extinction

Only small areas of ecosystems/habitats lost or converted

'Footprint' of dam avoids areas rich in species, endemic species, species at risk, or diverse habitats

In conclusion, mega dams and their reservoirs motivate the migration of species and matter from upstream to downstream; imbalance the turbidity in downstream that leads to soil and embankment corrosion; generates large organic debris; watering terrestrial and wildlife vegetation; huge loss of riverbank forest; disruption of population maintenance; impaired the wetland biodiversity; raise the exotic, weeds and diseases-prone microorganisms condition; sedimentation and heavy metal levels enhancement; seasonal variability of flow and flood plains; changes of water

\section{Environmentally threatening}

Several genetically distinct stock or species extirpated or driven to extinction

Large areas of ecosystems/habitats lost or converted

'Footprint' overlaps such areas

The ecological integrity of such areas is disturbed, hampering their biological productivity

Overall footprint of dam is large

Several exotic species or ecosystems introduced

Dam blocks routes of migratory freshwater species

Seasonal flow patterns of discharge disrupted

Discharge volume is greatly reduced. Zero discharges frequent or prolonged

Temperature, oxygen, turbidity, sediment, and acidity levels changed. Methyl mercury is generated.

Unique habitats lost

No EIA carried out, or a poor one hastily conducted with serious impacts neither avoided nor mitigated

Environment staff called in late in the project after key decisions irrevocably made, and their input is given low priority

Landscape and airspace planning and management not included in the process

Water volume stored is high and wastefully used

No protected areas established

Dam and irrigation canals leak, evaporation rates high

Dam reservoir sedimentation rate high

No such power storage devices used

Several genetically distinct stock or species extirpated or driven to extinction

Large areas of ecosystems/habitats lost or converted

'Footprint' overlaps such areas table characteristics; abiotic changes; changes in inland deltas; impacts on salinity, nutrients and reproduction; and, welcome the non dam impacts. One of the main considerations of dam impacts on biodiversity is placement in regard to species-rich areas. Priority should be given to guarantee that the environmental impact of dams does not overlap with biodiversity 'hotspots'. In areas rich in biodiversity and productive biological resources, it is also important to take into account the cumulative impact of dams. Two or more dams may have either serious cumulative or synergis- 
tic impacts [15].

\subsection{The Value of Biodiversity}

Globally terrestrial and aquatic ecological functions have been calculated to be minimally value US\$33 trillion per year, almost twice the value of the global gross national product, some $\$ 18$ trillion, although the figure contains the value of some biological resources as well as functions [16]. Costanza et al. (1997) specified that the annual per hectare total global flow value of inland water systems, US\$6,579 x 109 surpassed that from all other non-marine ecosystems combined - US\$5,740 x 109. Ecological functions, although not generally included in gross global or national/domestic products nevertheless make significant contributions to economies. Freshwater ecosystems are also economically more valuable than terrestrial ones. In many developing countries, fishes, including those from freshwater make a remarkable contribution in animal proteins to an otherwise carbohydrate-based diet. In the Amazon, the per capita consumption rate is $67 \mathrm{kgyr}-1$ higher than in many areas [17]. In Tonie Sap, Cambodia, 100,000 tonnes of freshwater fishes are caught annually, which source alone would provide a per capita $10 \mathrm{kgyr}-1$. Biodiversity has many kinds of values and potential benefits for humans and the world as a whole. The mega dams and the proposed ones in any region especially in the greater Himalayan region may significantly impose huge pressure to unvalued the precious biodiversity. Before it is diminished, those responsible may well wish to consider the protective principle and take action to preserve it before components of it are permanently lost, even when the evidence for loss is not as strong as might be desired [18].

\subsection{Standards for Minimizing Negative Impacts}

\section{on Biodiversity}

The continuous impairment of biological diversity due to the mega dams bound the inter-governmental community to fix a variety of mechanisms and a set of standards for minimizing harmful impacts on biodiversity. These legal standards were approved by almost all governments, are far more exacting and demanding than is generally recognized. On basis of different convention, agreements, and other corporate and government sector's analysis a few key points can be considered as the accepted standards for minimizing negative impacts on biodiversity-

-Species and ecosystems should be conserved in their in a way to provide benefits to humans.

-Effort should be given to minimize the risk of the extinction of species.

-Threatened species should get the priority.

-High priority should be given to securing the recovery of degraded habitats and ecosystems.

-Essential ecological functions or processes should be conserved.

-Natural resources should be used sustainably.

-There is concern that biodiversity continues to be lost at a rapid rate.

-Attempts to conserve biodiversity are hampered by inadequate information.

-Information flow should be continuous for conservation action.

-Environmental impact assessments should be thorough and transparent.

-Activities that have potential impacts on biodiversity should be the subject of prior

-Environmental impact assessments should be materialized firstly to assess serious negative impacts on biodiversity hence should not be permitted.

-Training campaign for the staff of biodiversity conservation should be standard and modern.

-Precautionary principle should apply in case of information lacking.

-Environmental impact assessment standards should be revised.

-Follow up- One, five and ten years follow-up biodiversity studies, by an organization other than the one which carried out the EIA, should be performed. These test EIA predictions and provide data for planning future dams.

It is important to realize that the above list summarizes the points that have been agreed by the global community through formal inter-governmental mechanisms.

\subsection{Impacts of Himalayan Dams to Global Warming}

The International Centre for Integrated Mountain Development, ICIMOD, in Nepal and the Intergovernmental Panel on Climate Change (IPCC) agree that global warming will also direct to more storms and floods, especially in tropical and mountainous regions. A recent report by ICIMOD on the impact of climate change on Himalayan glaciers illustrates: "On the Indian subcontinent, temperatures are predicted to rise between 3.5 and $5.5^{\circ} \mathrm{C}$ by 2100 [19]. An even higher increase is predicted for the Tibetan Plateau. Climate change is not just about averages, it is also about extremes. The changes in climate are affecting both minimum and maximum-recorded temperatures as well as prompting more extreme rainfall events and storms." These heavy storms and floods will endanger the economic profitability of hydropower projects, as well as the safety of these mountains of concrete. It may be added here that according to scientific estimates the large dams in India are responsible for about a fifth of the countries' total global warming impact [20]. The estimates also reveal that Indian dams are the largest global warming contributors compared to all other nations. A study from Brazil's National Institute for Space Research (INPE) estimates that emission of methane from all the reservoirs of the world could be $120 \mathrm{MT}$ per annum. Nitrous oxide and carbon dioxide from large dams were not included in the study. If all these are included, the global warming impact of large reservoirs would certainly go up further. The methane emission from Indian dams is estimated at $27.86 \%$ of the methane emission from all the large dams of the world, which is more than the share of any other country of the world [20]. Brazil 
secures the second position for the emission of methane from Brazil's reservoirs being $18.13 \%$ of the global figure. The consequent effects of dams are to increase the salinity in the downstream area like Bangladesh. During the postFarakka period, the southwest region of Bangladesh possessed high salinity (Table 1). For example, at the Khulna station, the average monthly maximum salinity for April in the pre-Farakka period was $1626 \mu \mathrm{mho} / \mathrm{cm}$. During 1976, when the Gorai discharge dropped to $0.5 \mathrm{~m} 3 / \mathrm{sec}$ from its pre-Farakka average of $190 \mathrm{~m} 3 / \mathrm{sec}$, maximum salinity in
April increased to $13,000 \mu \mathrm{mho} / \mathrm{cm}$. Moreover, it may result also the socio-economic and environmental degradation in the floodplain area of downstream area like corrosion, water quality degradation, health hazard, agricultural production etc (Figure 2). In addition, water discharge rate in the downstream also reduced with alarming rate. Mean monthly discharge of the Ganges River at Hardinge Bridge in Bangladesh for the seven months of the dry season. Spectacular effects of diversion are noticed in the mean monthly discharges (Figure 3).

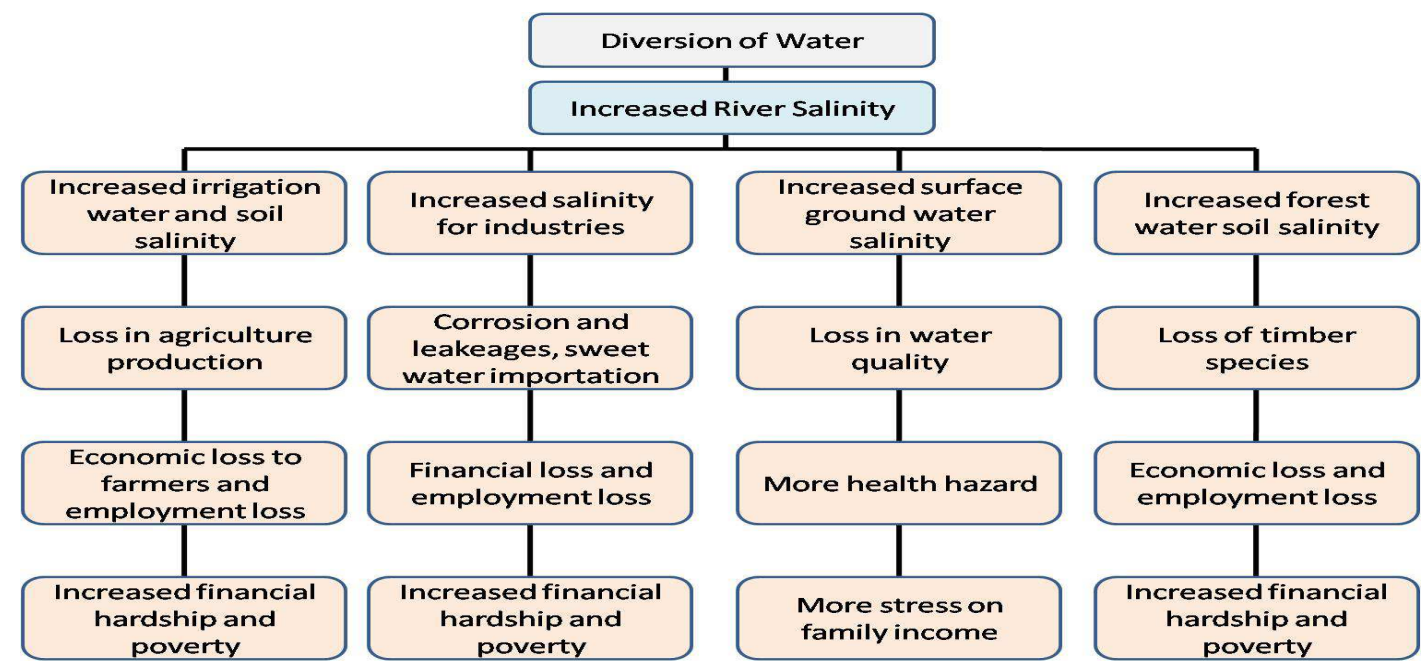

Figure 2. Increased river salinity and its possible effects.

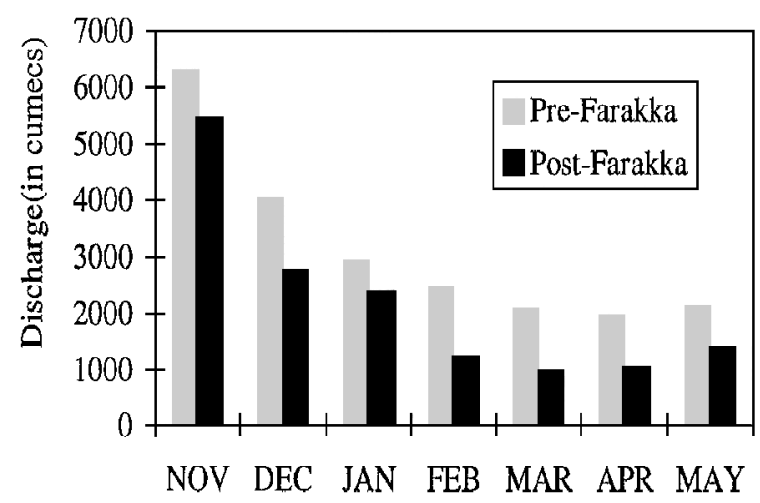

Figure 3. Dry season (November-May) mean monthly discharge of the Gorai River. Cumecs refers to $1 \mathrm{~m}^{3} / \mathrm{sec}$ flow of water [20].

Global warming might be the most serious challenge to the safety and efficiency of the proposed dams in the Himalayan region, but the funding gap appears to be hampering India and Pakistan moving ahead with the largest planned dams for the region, including the Diamer-Bhasha project. It also appears that strong local opposition to some of the major projects, including the West Seti project and the 3,000-MW Dibang project in Arunachal Pradesh, India, constitute larger obstacles for the project planners than anticipated. Planned public hearings for the Dibang project have had to be cancelled several times due to strong opposition. Perhaps most surprising, it is no longer clear that large hydro-dams are even a consistently climate-friendly source of energy. While hydro-electricity can be a substi- tute for carbon-dioxide producing fossil fuels, the reservoirs behind big dams often include large amounts of rotting vegetable matter and thus are a significant source of methane a much more potent greenhouse gas. These methane emissions are larger in tropical and sub-tropical climates, where vegetation both grows and decays faster [21$25]$.

A 2007 study suggested that methane from dam reservoirs actually accounted for 19 per cent of India's greenhouse-gas emissions, while hydro-power accounts for only 16 per cent of the country's electricity and less still of its total energy use. These figures are still preliminary estimates; methane emissions may be lower than average for dams high in the Himalayas, which is not an area where plant matter grows or decays rapidly; and there may be ways to mitigate these effects, by capturing and burning the methane to generate more power. But they call into question the common assumption that, despite the environmental risks, large dams are a 'greener' energy source than most alternatives; the non-trivial greenhouse emissions involved in creating huge amounts of concrete and steel further complicate the picture.

\section{Feasibility of the Dam Projects}

The critical question, however, is that in a very high seismic sensitive region, is it safe to construct massive hydro-electric power projects? The recent international studies indicate that the construction of a mega dam and crea- 
tion of a huge water body in severe seismic sensitive regions on the earth is not advisable, considering the complex geological aspects [14]. For example, the 7.9 magnitude quake that had struck the entire Sichuan Province of China in May 2008, killing more than 80,000 people and leaving more than five million homeless, was due to the failure of the 511-ft 'Zipingpu Dam', which holds 315 million tonnes of water and lies near a geological fault-line and only three miles away from the earthquake's epicenter. The similar disaster cannot be ruled out in the event of constructing the Tipaimukh Dam on the Barak River - that runs along a similar geologic formation - in the southern most part of Assam in NE India.

\section{Tipaimukh Dam: A Case Study}

Another ominous factor for Bangladesh is the Tipaimukhi Dam which was initiated in 1948; a high capacity dam would be created in the Tipaimukhi Hydroelectric project of India having a height of 162.8 meter. The water containing power of this dam is 15.5 billion cubic meter and electricity produce capacity is 1,500 megawatt. 226 big dams would be created in their convenient places in south east of India to produce 99,000 megawatt electricity within the next 50years. It would be created align the border of Karimganj of Assam above the River Borak. This Borak River is the main stream of the Branch Rivers; Surma and Kushiara. Both these rivers conjointly created the big Meghna in Bangladesh. This river has a high speed stream and a high capacity to contain sand than the River Padma. India took a target to produce 50,000 megawatt of electricity by 2012.The Tipaimukhi High Dam is situated very adjacent to Bangladesh border. This project would result gathering massive collection and flow of sand under river, sudden flood, floods. All this reactions would be seen at the northeast region and especially at the Haor localization. Total scenario of this area would be changed drastically (figure 4). All the Haor, marshy lands, ponds rivers, embankments would be filled with sand of this region within 10-15 years. The fertile land of the Haor would turn into desert. Agriculture would be destroyed. Rice grains like Boro, Shail and Aman would lose its regional diversity. Biodiversity of this region would be lost. Plants, aquatic plants, traditional fish, and the infrastructure of this region would be in vain [5].

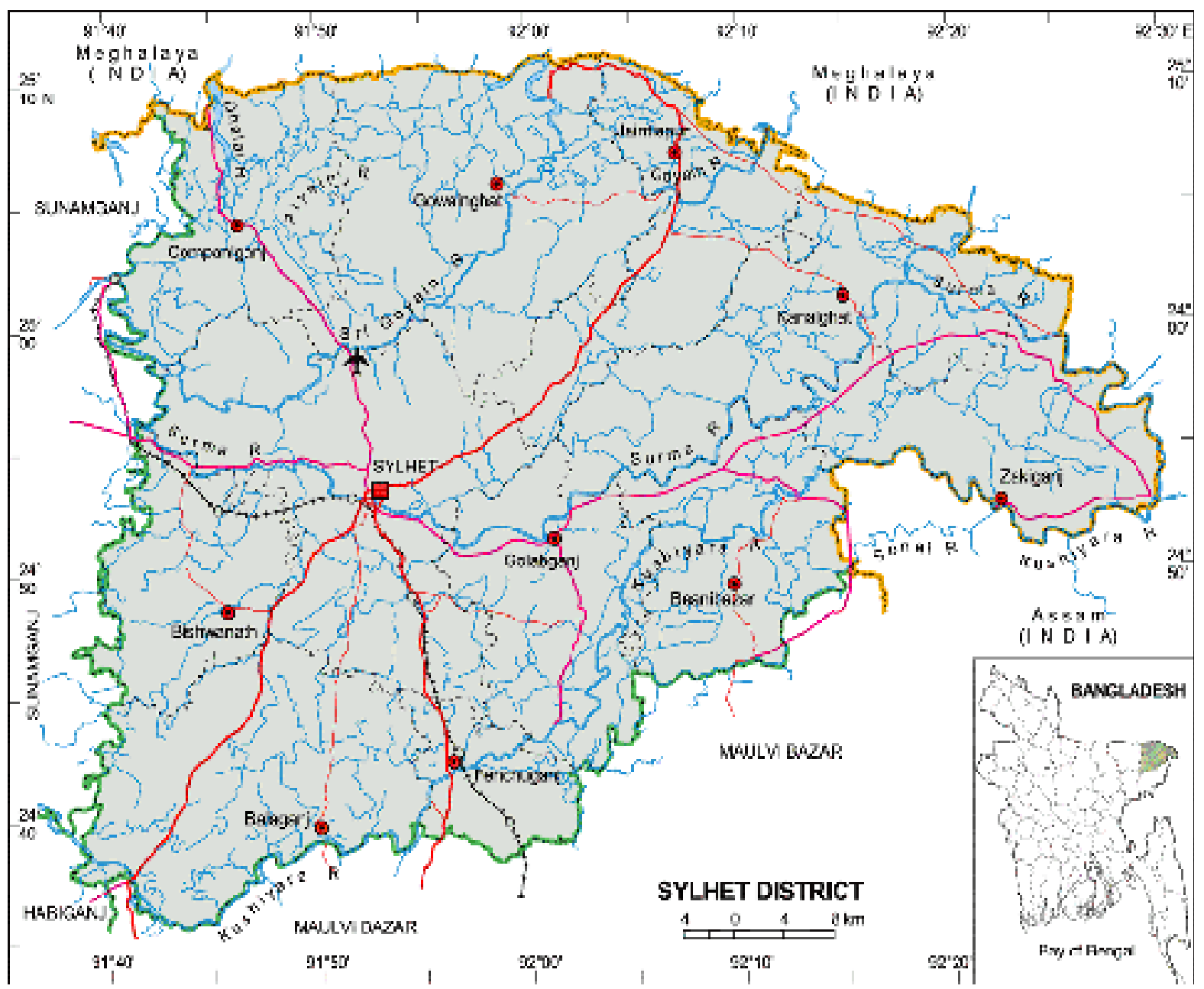

Figure 4. The map shows the part of Bangladesh that would get affected by the Tipaimukh Dam Project by India.

The total ecosystem of this region would be jeopardized. If the rivers Surma and Kushiara die there would be no
Meghna River in Bangladesh. Thus it is not only Sylhet and the Hawor localization that is in danger but also the locali- 
zation around Meghna is in big risk. Economy of the country and the normal life of the people of Bangladesh would be paralyzed [23].

\section{Conclusion}

In the Himalayas the threat from the concrete works that would include huge walls damming the rivers, underground tunnels that could go scores of kilometer long, that could completely bypass and dry up the rivers for even longer lengths, the massive blasting that would be required for the same, the power houses, the roads, the townships, the mining that would be necessary to procure the materials for the projects, the hundreds of kilometer long transmission lines meant for the power promised to be generated, threats from all this is indeed of Himalayan proportions. And even if it cannot dwarf the mountain itself, certainly it has the potential to destroy large parts of it permanently.

Dams are a principal threat to environment mostly in freshwater diversity and that threat is largely mediated through loss of habitat frequently involving modifications to the natural flow regime and to blockage of migrations. Putting aside the enormous cost involved in constructing nearly 80 dams in the four countries stated above, it would not be wrong to question the wisdom of constructing them in fragile, erosion prone, landslides prone, active seismic zone.

In view of the above the prudent course would be for the Himalayan countries to develop water resources in a way that helps people of the region adapt to the changing climate as well as hydro-geologic characteristics and reduces their risks. The concerned countries of this region, therefore, should work together to forge a common platform for water resource management planning vis-à-vis river basin management that should be above opportunistic short term political interests but dedicated to a longer term regional socioeconomic development of the people with a common goal to safeguarding and ensuring a sustainable regional environment.

\section{Acknowledgements}

The authors are grateful to every faculty members of department of Environmental Science, Stamford University Bangladesh for their kind assistance in collecting information. Reports of IPCC and IUCN has been extensively analyzed in this research and thereby acknowledged.

\section{References}

[1] R. B. Barthem, M. C. Ribeiro, M. Petrere, "Life strategies of some long-distance migratory catfish in relation to hydroelectric dams in the Amazon Basin," Biological Conservation, vol. 55, pp. 339-345, 1991.

[2] R. S. Devine, "The trouble with dams," Atlantic Monthly, vol. 276, pp. 64-74, 1995.
[3] S. A. Abbasi, "Wetlands of India: ecology and threats" Discovery Publ. House, New Delhi, India, Vol. 1. p. 9, 1987.

[4] D. R. Blu"hdorn, A. H. Arthington,"The utility of stream salinity models in the integrated management of Australian rivers," in David M. Harper and Alastair J. D. Ferguson, John Wiley \& Sons Eds. New york: The ecological basis for river management, 1995, pp. 115-124.

[5] GOB (Government of Bangladesh), "White paper on the Ganges water dispute," GOB, Dhaka, 1976.

[6] M. M. Q. Mirza, "Diversion of the Ganges Water at Farakka and Its Effects on Salinity in Bangladesh," 2005.

[7] C. Revenga, S. Murray, J. Abramovitz, A. Hammond, "Watersheds of the world: Ecological value and vulnerability," Worldwatch Institute, Washington, DC, 1998.

[8] GOB (Government of Bangladesh),"Ganges water: Crisis in Bangladesh," GOB, Dhaka, 1997.

[9] M. B. A. Saad, "Conflicts between users. Sustainable fish production in Lake Nasser: ecological basis and management policy," In: J.F. Craig (Editor), ICLARM Conference Proceedings, vol. 61, pp. 7-9, 2000.

[10] R. A. Bodaly, R. E. Hecky, R. J. P. Fudge, "Increases in fish mercury levels in lakes flooded by the Churchill River diversion northern Manitoba, Canada," Canadian Journal of Fisheries and Aquatic Sciences, Vol. 41, pp. 682-691, 1984.

[11] JRC (Indo-Bangladesh Joint Rivers Commission), "Monthly maximum salinity data for various stations," Dhaka, 1995.

[12] T. Dorcey, A. Steiner, M. Acreman, B. Orlando, "Large dams. Learning from the past, looking at the future. Workshop Proceedings, IUCN, Gland Switzerland and Cambridge, UK and the World Bank Group, Washington, DC, pp. $145,1997$.

[13] M. P. McCartney, C. Sullivan, M. Acreman, "Ecosystem impacts of large dams. Report for the IUCN-The World Conservation Union and the World Commission on Dams," pp. 74, 1999.

[14] I. Goldsmith, N. Hildyard, "The social and environmental effects of large dams. Volume One, Overview," The European Ecological Action Group, UK, p. 346, 1984.

[15] P. McCully, "Silenced rivers. The ecology and politics of large dams," Zed Books, London \& New Jersey, pp. 350, 1996.

[16] R. Costanza, R. Arge, R. Groot, S. Farber, M. Grasso, B. Hannon, K. Limburgh, S. Naeem, R. V. O’Neil, J. Paruleo, R. G. Raskin, P. Sutton, M. van den Belt, "The value of the world's ecosystem services and natural capital," Nature, vol. $15,1997$.

[17] L. N. Chao, L. Sonnenschein, S. Dowd, "Project PIABA. Developing toward a sustainable natural resource in Amazon freshwater fisheries," Bio-Amazonia Conservation International, Brookline, Maine and Universidade do Amazonas, Manaus, Brazil, pp. 34, 1999.

[18] M. Kottelat, T. Whitten, "Freshwater biodiversity in Asia with special reference to fish," World Bank Technical Paper, vol. 343, pp 59-75, 1996.

[19] IPCC (Intergovernmental Panel on Climate Change), "Fourth Assessment Report: Climate Change 2007," IPCC 
statement on the melting of Himalayan glaciers, Geneva, 2010 .

[20] A. H. Khan,"Farakka Barrage: Its impact on Bangladeshan overview," Dhaka, 1993, pp. 13.

[21] M. T. Sikder, M. Yasuda, Yustiawati, S. Syawal, T. Saito, S. Tanaka, M. Kurasaki, "Comparative Assessment of Water Quality in the Major Rivers of Dhaka and West Java," Int. J. Environ. Protec. Vol. 2, pp. 8-13, 2012.

[22] S. M. A. Hussainy, "Major environmental problems of Bangladesh: An overview," Dhaka, 1987, pp.33.

[23] SRDI (Soil Resource Development Institute)," Soil Salinity in Bangladesh 2000," Government of the People Republic of Bangladesh, 2003.

[24] M. T. Sikder, Y. Kihara, M. Yasuda, Yustiawati, Y. Mihara, S. Tanaka, D. Odgerel, B. Mijiddorj, S. M. Syawal, T. Hosokawa, T. Saito, M. Kurasaki, "River Water Pollution in Developed and Developing Countries: Judge and Assessment of Physicochemical Characteristics and Selected Dissolved Metal Concentration," Clean-Soil Air Water. Vol. 41, pp. 6068, 2013.

[25] R. T. Watson, M. C. Zinyowera, R. H. Moss, "Climate change 1995. Impacts, adaptations and mitigation of climate change: Scientific-technical analyses," Contribution of Working Group II to the Second Assessment Report of the Intergovernmental Panel on Climate Change, Cambridge University Press, Cambridge, UK, pp. 878, 1996. 